\title{
A THEORY OF CHILD'S GAME OF F. FROEBEL AND K. USHYNSKYI AND CAPABILITIES OF ITS USE IN PROFESSIONAL TRAINING OF THE MOBILE-ORIENTED PHYSICAL EDUCATION TEACHER
}

\author{
ТЕОРІЯ ДИТЯЧОЇ ГРИ Ф. ФРЕБЕЛЯ І К. УШИНСЬКОГО \\ ТА МОЖЛИВОСТІ ЇЇ ВИКОРИСТАННЯ \\ У ПРОФЕСІЙНІЙ ПІДГОТОВЦІ МОБІЛЬНО \\ ЗОРІЕНТОВАНОГО ВЧИТЕЛЯ ФІЗИЧНОЇ КУЛЬТУРИ
}

\author{
Natalia Denysenko ${ }^{1}$ \\ Serhiy Marchuk ${ }^{2}$
}

DOI: https://doi.org/10.30525/978-9934-26-001-8-1-3

Abstract. In modern educational conditions the problem of professional mobility of the future Physical Education teacher acquires actual value. This is what strengthens the special interest in the ideas of child's physical development through the prism of game technologies, which were put forward by educators of the past and have not lost their importance today. Analysis of the creative heritage of outstanding educators makes it possible to use historical experience in the development of modern education. The works of the German teacher F. Froebel and the Ukrainian K. Ushynskyi, wich study the theory of children's game, are of considerable interest nowdays.

The subject of research is the pedagogical possibilities of children's games by F. Froebel and K. Ushynskyi in the professional training of a mobile-oriented PE teacher in modern educational conditions.

The purpose of the study is to substantiate the effectiveness of game methods of the child's physical development in the process of future

\footnotetext{
${ }^{1} \mathrm{PhD}$ in Pedagogy, Dean of the Department of Primary Education and Physical Culture, Associate Professor at the Department of Physical Culture, Public Higher Education Institution "Lutsk Pedagogical College" of the Volyn Regional Council, Ukraine

${ }^{2} \mathrm{PhD}$ in Pedagogy, Head of the Department of Pedagogy, Psychology and Separated Methodologies,

Public Higher Education Institution "Lutsk Pedagogical College" of the Volyn Regional Council, Ukraine
} 
PE teachers training to implement the pedagogical ideas of F. Froebel and $\mathrm{K}$. Ushinskyi in the modern space of higher physical education.

Objectives of the study: studying the problem of children's play in the pedagogical concepts of F. Froebel and K. Ushinskyi, outlining ways of creative use of ideas of F. Froebel and K. Ushinskyi in the formation of professional mobility of future PE teachers in the process of practical preparation for play activity of young pupils.

The methodological basis of the study is the pedagogical heritage of F. Froebel and K. Ushinskyi; theory of scientific knowledge. The study is based on the principles of historicism, systematics, scientificity, mobility, child-centeredness, creative approach to the personality as a subject of the educational process.

The scientific novelty of the study is, that: a comparative analysis of game methods of the child's physical development through the prism of pedagogical systems of F. Froebel and K. Ushinskyi is given for the first time; the process of professional training of future PE teachers is modeled on F. Froebel's pedagogical ideas; further development of the content and methodological support for the formation of professional mobility of future teachers to implement the provisions of F. Froebel and K. Ushinskyi on children's play activities.

Friedrich Froebel (1782-1852) developed the theory and methodology of the game as a means of harmonious development of the child. His system of preschool education was extremely widespread in the world, and is also used today in Europe, particularly in Germany.

Konstantin Ushinskyi (1824-1870) formulated the following pedagogical conclusions about the game: games predict the future character and destiny of the child; the game has a great influence on the development of children's abilities; children's games have their nationalities, their centuries-old history; children are constantly creating new games.

The study led to the following conclusions:

1. The study of the theory of children's play in the pedagogical concept of F. Froebel showed that it is based on the principles of child centrism, creativity, amateurism, children's self-development, fun, constructive activity through the expression of children's feelings, thoughts, gestures, songs, stories.

2. K. Ushinsky defines the importance of game in the physical and mental development of the personality, argues and critically evaluates the 
«children's gifts» of F. Froebel. Theoretical and practical study of children's games in modern conditions is an important professional competence of future PE teachers, methodical provisions on their expediency were substantiated by K. Ushinskyi. The conducted historical and pedagogical analysis of the works of F. Froebel and K. Ushinskyi testifies to the important scientific achievements of teachers in the field of children's play theory.

3. Froebel's didactic material was aimed at mastering by students the method of developing children's physical abilities, their ability to constructive activity, logical thinking, which today acquires special significance not only in physical education but also in professional sports. Froebel's pedagogy is designed to educate the future teacher not only of physical culture, but also «culture» in the broadest sense of the word, forms his professional and mobile competencies of the combinatorial type.

4. Necessary pedagogical conditions for the implementation of the main tasks of physical education in the scientific heritage of $\mathrm{K}$. Ushinskyi are compliance with the principles of humanism, nationality, conformity to nature, rational use of effective ways, means and forms of strengthening and preserving mental and physical health of students on the requirements of high moral and professional qualities of teacher's personality.

\section{1. Вступ}

Питання пошуку сучасного змісту підготовки майбутніх учителів фізичної культури $є$ найбільш пріоритетною у зв' язку із світовими тенденціями щодо зміни парадигми вищої фізкультурної освіти. Йдеться про розроблення теоретико-методологічних засад формування професійної мобільності вчителя нової генерації, здатного до реалізації інноваційної освітньої політики у галузі фізичного виховання та спорту.

Стратегічні завдання та вимоги до рівня професійної підготовки майбутніх учителів фізичної культури викладені у Законах України «Про освіту», «Про повну загальну середню освіту», «Про вищу освіту», «Про фізичну культуру і спорт», Національній доктрині розвитку фізичної культури і спорту, Національній стратегії з оздоровчої рухової активності в Україні на період до 2025 року та ін.

У сучасних освітніх умовах проблема професійної мобільності майбутнього вчителя фізичної культури набуває актуального значення. Саме це і підсилює особливий інтерес до ідей фізичного розвитку 
дитини через призму ігрових технологій, що були висунуті педагогами-просвітителями минулого і не втратили своєї актуальності сьогодні. Адже Закон України «Про освіту» важливими принципами сучасної освітньої діяльності визначає пріоритетність: гуманізму; демократизму; єдності навчання, виховання та розвитку; нерозривного зв'язку зі світовою та національною історією, культурою, національними традиціями; інтеграції у міжнародний освітній та науковий простір [5].

Серед робіт, виконаних у межах означеної проблеми, відзначимо наукові розвідки Н. Бєлікової, О. Біницької І. Грінченко, Л. Сущенко, В. Триндюк, І. Шаповалової, які вивчали окремі аспекти мобільності і приділяли значну увагу підготовці майбутніх учителів з фізичної культури в умовах нової української школи. Узявши до уваги рекомендації українського компаративіста А. Сбруєвої щодо методологічної основи порівняльно-педагогічних досліджень [7, с. 32], ми вивчаємо професійну мобільність 3 урахуванням філософських, психолого-педагогічних і соціологічних теорій, що дає можливість виявити історико-культурну детермінованість цього педагогічного феномена, розкрити його багатовимірність, відібрати позитивний досвід для української освіти сьогодні й на перспективу.

Цілком закономірним є й усвідомлення необхідності об'єднання зусиль представників різних наук і різних історичних епох «про людину» для напрацювання інтегрованої теорії формування мобільного учителя фізичної культури.

Сучасна дидактика базується на ідеях, які були висунуті педагогами-гуманістами минулого і не втратили своєї актуальності в наш час. Особливий інтерес викликає педагогічна спадщина Ф. Фребеля та К.Ушинського, зокрема запропоновані ними ігрові методики для фізичного розвитку дитини.

Дозволимо зупинитися на історико-педагогічній методології щодо формування професійної мобільності майбутніх учителів фізичної культури. Адже історія $є$ тим науковим підгрунтям, в якому зберігаються цінні та перевірені часом погляди відомих дослідників освітніх перетворень. Історична освітня традиція спонукає нас до пошуку нових шляхів і форм досягнення поставлених наукових завдань.

У XIX - поч. XX ст. у зарубіжній і вітчизняній педагогічній теорії та практиці зростає інтерес до дитячих ігор. Дослідники цього періоду 
(П. Лесгафт [2], Н. Лубенець [3], М. Монтессорі [4], К. Ушинський $[8 ; 9 ; 10 ; 11]$, Ф. Фребель [12; 13]) рухливі ігри розглядали як важливий засіб фізичного виховання дітей. Відомий польський педагог Януш Корчак зазначав: «Гра - це не тільки стихія дитини, але й єдина сфера, де ми дозволяємо ій ініціативу у вужчому чи ширшому діапазоні. Під час гри дитина до певної міри відчуває себе незалежною. Усе інше $\epsilon$ швидкоплинною послугою, хвилинним правом, а дитина має право на гру» [14]. Аналіз творчої спадщини видатних педагогів дає можливість використовувати історичний досвід у розвитку сучасної освіти. Значний інтерес становлять праці німця Ф. Фребеля та українця К. Ушинського, в яких досліджено теорію дитячої гри.

Предмет дослідження - педагогічні можливості дитячих ігор Ф. Фребеля та К. Ушинського у професійній підготовці мобільно зорієнтованого вчителя фізичної культури в сучасних освітніх умовах.

Мета дослідження полягає в обгрунтуванні ефективності ігрових методик фізичного розвитку дитини у процесі підготовки майбутніх учителів фізичної культури до впровадження педагогічних ідей Ф. Фребеля та К. Ушинського в сучасному просторі вищої фізкультурно-педагогічної освіти.

Завдання дослідження:

1. Вивчити концепцію дитячої гри в педагогічній спадщині Ф. Фребеля.

2. Проаналізувати критичні думки К. Ушинського на проблему дитячої гри Ф. Фребеля.

3. Окреслити шляхи творчого використання ідей Ф. Фребеля у формуванні професійної мобільності майбутнього вчителя фізичної культури у процесі практичної підготовки до ігрової діяльності молодших школярів.

4. Визначити положення «здорової педагогіки» К. Ушинського, які оптимізують професійну підготовку мобільно спрямованого майбутнього вчителя фізичної культури в умовах нової української школи.

Методологічною основою дослідження педагогічна спадщина Ф. Фребеля та К.Ушинського; теорія наукового пізнання; положення Національної доктрини розвитку фізичної культури і спорту; доцільність використання демократичних та прогресивних ідей творчого використання спадщини видатних педагогів у сучасній освітній практиці. Дослідження базується на принципах історизму, системності, 
науковості, мобільності, дитиноцентризму, творчого підходу до особистості як суб'єкта освітнього процесу.

Наукова новизна дослідження полягає в тому, що: вперше подається порівняльний аналіз ігрових методик фізичного розвитку дитини крізь призму педагогічних систем Ф. Фребеля та К. Ушинського; змодельовано процес професійної підготовки майбутніх учителів фізичної культури на педагогічних ідеях Ф. Фребеля; подальшого розвитку набуло змістовно-методичне забезпечення формування професійної мобільності майбутніх педагогів до впровадження положень Ф. Фребеля та К. Ушинського щодо ігрової діяльності дітей.

\section{2. Концепція гри в педагогіці Ф. Фребеля}

Фрідріх Фребель (1782-1852) розробив теорію та методику гри як засобу гармонійного розвитку дитини. Його система дошкільного виховання була надзвичайно поширеною у світі, а також використовується сьогодні у Європі, зокрема в Німеччині.

Ф. Фребель прагнув допомогти дитині виразити свої почуття і думки за допомогою жесту, пісні і мови. Він організовував дитяче життя у формі ігор, забав, конструктивної діяльності, оповідань, що допомогли б дитині в іiі прагненні до самопрояву, і давали б учителеві матеріал для керівництва інтересами і діями дитини.

Велика заслуга Ф. Фребеля полягає в тому, що він відмітив величезне розвиваюче, виховне та освітнє значення дитячої гри. Учений вважав, що саме у грі найкраще проявляється творчість і самодіяльність дитини, що, однак, не виключає керівного впливу дорослих на ігри дітей. У його праці «Дитячий садок» [10] докладно розроблено цілу систему дитячих ігор і підкреслив самостійне місце гри в системі дошкільного виховання.

Першими іграми дитини є так звані дари (дарунки) Фребеля (табл. 1).

Дослідник подає конкретні методичні поради щодо використання іграшки п'ятого дарунка.

1. Застосування завжди починається з усебічного огляду всього кубика як єдиного і з усіх боків рівномірно замкненого в собі цілого, отже, з чіткого уявлення щільно складеного кубика.

2. Цього можна досягти дуже легко тим, що, вкладаючи кубик в ящик, спершу кладуть кубики, поділені на частини, на низ і саме так, 
Дарунки для ігор (Spielgaben) Ф. Фребеля [13]

\begin{tabular}{|c|c|}
\hline Дарунки для ігор & $\begin{array}{c}\text { Характеристика дарунку. } \\
\text { Методичні поради дорослому }\end{array}$ \\
\hline Перший дарунок & $\begin{array}{l}\text { М'яч - перша дитяча іграшка. М'які, зв'язані з шерсті } \\
\text { невеликі м'ячі, забарвлені в різні кольори: червоний, } \\
\text { оранжевий, жовтий, зелений, синій. Фіолетовий і білий. } \\
\text { Кожний м’яч - на ниточці. Тримаючи за неї, мати показує } \\
\text { дитині м’ячі різних кольорів, розвиваючи таким чином } \\
\text { уміння дитини розрізняти кольори. Розгойдуючи кульку в } \\
\text { різні сторони і відповідно наспівуючи: «Вперед - назад», } \\
\text { «Вгору - вниз», «Вправо - вліво», мати знайомить дитину } \\
\text { з просторовими уявленнями. Показуючи м'ячик на долоні } \\
\text { і ховаючи його, мати приказує: «Є м’ячик - нема м’ячика», } \\
\text { тобто знайомить дитину із ствердженням і запереченням }\end{array}$ \\
\hline Другий дарунок & $\begin{array}{l}\text { Куля й кубик як друга іграшка дитини. Невеликі дерев’яні } \\
\text { кулька, кубик і циліндр. Дитина знайомиться з різними } \\
\text { формами предметів; кубик своїми площинними формами } \\
\text { і своєю стійкістю є ніби запереченням кулі; циліндр } \\
\text { поєднує і властивості кулі, і властивості куба: він стійкий, } \\
\text { будучи поставлений на основу, і рухливий, будучи } \\
\text { покладений, і т.д. }\end{array}$ \\
\hline Третій дарунок & $\begin{array}{l}\text { Кубик, поділений через центр на частини з усіх сторін } \\
\text { i паралельно їм. Іграшка - куб, поділений на } 8 \text { кубиків } \\
\text { (куб розрізано пополам, кожну половину - на } 4 \text { частини). } \\
\text { У дитини формується уявлення про ціле і складові } \\
\text { його частини. Дитина має можливість розвивати свою } \\
\text { творчість, дещо будувати з кубиків, різно їх комбінуючи }\end{array}$ \\
\hline Четвертий дарунок & $\begin{array}{l}\text { Кубик, поділений на } 8 \text { кубиків-брусків. Кубик ділиться } \\
\text { навпіл, а кожна половина - на } 4 \text { здовжені плитки; довжина } \\
\text { кожної плитки дорівнює стороні кубика, товщина } \\
\text { дорівнює чверті цієї сторони. Можливість будівних } \\
\text { комбінацій з цим четвертим даром значно розширюється: } \\
3 \text { додаванням кожного нового дару попередні, з якими } \\
\text { дитина вже освоїлась, звичайно, не забираються }\end{array}$ \\
\hline П’ятий дарунок & $\begin{array}{l}\text { Кубик, двічі рівномірно поділений у всіх трьох напрямках } \\
\text { на маленькі кубики, три з яких, у свою чергу, поділяються } \\
\text { по діагоналі навпіл, а інші три - по двох діагоналях на } \\
\text { четвертини. Кубик, поділений на } 27 \text { малих кубиків, при } \\
\text { чому } 9 \text { з них поділені на ще менші частини } \\
\end{array}$ \\
\hline Шостий дарунок & $\begin{array}{l}\text { Кубик, поділений на } 27 \text { цеглинок, з яких } 3 \text { поділені навпіл } \\
\text { уздовж, а } 12 \text { - навпіл упоперек. Шостий дарунок Фребель } \\
\text { не схарактеризував [13] }\end{array}$ \\
\hline
\end{tabular}


аби кубики в поділах будь-якого одного роду лежали в одному і тому самому ряду. Тому саме дно ящика займе ряд неподілених кубиків, ряд поділених навпіл і ряд поділених на чотири частини. Останні 18 цілих кубиків заповнюють решту простору в ящику. Перед дитиною, що грається, з'явився цілий кубик, складений у певному порядку.

3. Добре, якщо іграшку завжди дають дитині впорядкованою.

4. Добре, якщо дитина починає гру з огляду цілого, тобто замкненої в собі простої єдності, і вже $з$ неї розвиває свої духовні образи, свої невиразні уявлення.

5. Дуже важливо, щоб дитина, яка грається, завжди могла оглянути матеріал для гри, розміщений за змістом, щоб завдяки цьому в неї невимушено складався і план його використання [13, с. 91].

Після цих дарів Ф. Фребель пропонує дитині ігри з будівним матеріалом (дерев'яні тіла різної форми), з якого дитина будує башти, вікна i ворота тощо. Ігри з будівним матеріалом, які розвивають комбінаторні здібності дитини, з часів Ф. Фребеля міцно ввійшли в побут дитячого життя. Крім того, Ф. Фребель запровадив ігри з паличками, горохом, а також різні заняття для дітей: виколювання по контуру, малювання, аплікації, ліплення, плетення з кольорових смужок паперу та ін., а також рухливі ігри [1, с. 377].

Дослідниця Н. Лубенець зазначає, що вивчаючи дітей в усі моменти ïх життя, Ф. Фребель дійшов висновку, що найповніше і найяскравіше діти виявляють себе в іграх і саме ігри є природним життям дитини. Тому він надає надзвичайно важливого значення спостереженню за дитячими іграми.

Визнаючи за дітьми право на свободу в іграх і вважаючи, що Ф. Фребель відводить надто багато місця іграм під керівництвом вихователя i за його участю, ми все-таки маємо погодитися з тим, яке важливе i, безумовно, необхідне спостереження за вільними іграми дітей і вміле втручання старших. У наш час у навколишньому житті ще дуже багато грубості, насильства, бруду і жорстокості, які усмоктуються дітьми, дуже часто відтворюються в іграх, i, таким чином, вони сприймають їх ще глибше і міцніше [3, с. 285].

С. Русова вважала, що фребелівські ігри не забезпечують «різноманітності в рухах»: діти або стоять, або бігають, дитина весь час на ногах і швидко втомлюється. Метод М. Монтессорі більше імпону- 
вав відомій діячці, бо дитина здійснювала у процесі гри різноманітні рухи: лазила, перекидалася, гойдалася тощо. С. Русова відзначає, що саме Ф. Фребель «поклав певний принцип початкового навчання й виховання відповідно до того, як саме робив і навчав роботи великий Песталоцці: цей принцип має на меті міцно зв'язати знання з умінням, викликати інстинкт дитини до праці, до творчості» [6, с. 58].

\section{3. Ідеї К. Ушинського та критика дитячих ігор Ф. Фребеля}

Видатні діячі дитячого виховання (Є. Водовозова, Н. Лубенець, С. Русова, А. Симонович, К. Ушинський) вивчали та аналізували педагогічну систему Ф. Фребеля, висловлювали власне бачення щодо використання його ідей відповідно до особливостей національного виховання та соціокультурних умов своєї країни.

Видатний вітчизняний педагог Костянтин Ушинський (1824-1870) часто у своїх творах звертається до ігрової діяльності дітей, педагогічного значення гри у фізичному та психічному розвитку особистості, до наукових теорій їх виникнення. Зокрема, у монографії «Людина як предмет виховання. Спроба педагогічної антропології» $є$ стаття «Виховне значення дитячих ігор» [9, с. 295-298]. Педагог, описуючи дитячі заклади та родинне виховання у «Звіті відрядженого за кордон» [8, с. 196-197, 201-204], звертається до ігор Ф. Фребеля.

У табл. 2 узагальнимо наукові положення Ф. Фребеля та К. Ушинського щодо дитячих ігор.

К. Ушинський, використовуючи науковий спадок Ф. Фребеля щодо ігор дітей, критикує німецького педагога-новатора й окреслює перспективи майбутнього дослідження цієї проблеми:

1. Він надто захопився іграми, систематизував і вигадав багато таких, у яких мало дитячого (бо придумати дитячу гру - одне 3 найважчих завдань для дорослого).

2. Фребель зробив би, може, краще, коли б розробив ті дитячі ігри, які придумані вже століттями і в які граються і російський хлопчик, i маленький італієць, і маленький індус на берегах Гангу, у які грають і наші діти, гралися і діти стародавніх греків та римлян.

3. Дитячі ігри чекають ще свого історика, який із подивом помітить, що будь-яка гра 3 надзвичайною правильністю і точністю, втративши іноді сенс, передавалася з покоління до покоління через декілька тисячоліть. 


\section{Думки Ф. Фребеля та К. Ушинського про рухливі ігри дітей}

\begin{tabular}{|c|c|}
\hline 13 , с. $92-94]$ & ий $[9$, с. 296-297] \\
\hline $\begin{array}{l}\text { Якщо ми хочемо впливати благотворно } \\
\text { на майбутню діяльність дитини, на } \\
\text { майбутнє їі творчої діяльності і якщо } \\
\text { ми хочемо дати їй міцну основу, то } \\
\text { ми маємо уважно спостерігати за } \\
\text { початковою діяльністю дитини і } \\
\text { доглядати за нею, отже, і за ії першим } \\
\text { рухом, за їі першими кроками }\end{array}$ & $\begin{array}{l}\text { Ігри провіщають майбутнє дитини, для } \\
\text { неї гра - дійсність, і дійсність значно } \\
\text { цікавіша, ніж та, що навколо неї. У } \\
\text { ранньому віці гра має більше значення } \\
\text { для розвитку дитини, ніж навчання. } \\
\text { Гра для дитини становить те, що для } \\
\text { дорослої людини будь-яка серйозна } \\
\text { діяльність }\end{array}$ \\
\hline $\begin{array}{l}\text { Ігри дають можливість створювати } \\
\text { і вправляти самостійну здатність } \\
\text { рухатися і ходити: це - освітні } \\
\text { подорожі, це - ігри, що дають багатий } \\
\text { запас спостережень і досвіду }\end{array}$ & $\begin{array}{l}\text { Уважно стежте за іграми дитини, вона } \\
\text { тут виявляє свій духовний світ; для } \\
\text { дитини гра - дійсність; у грі дитина } \\
\text { живе, пробує свої сили і самостійно } \\
\text { керує своїми фантазіями }\end{array}$ \\
\hline $\begin{array}{l}\text { Я дивився, як діти рухаються, і дійшов } \\
\text { висновку, що є певний закон, за яким } \\
\text { вони рухаються. } 3 \text { цими рухами } \\
\text { пов’язуються маленькі рими. Ці рими } \\
\text { звучать у співі; рух, рима і звук - усе } \\
\text { це пов’язано воєдино; тілесна, духовна } \\
\text { й моральна діяльність - все поєднано у } \\
\text { прекрасному цілому }\end{array}$ & $\begin{array}{l}\text { Гра тому іє грою, що вона самостійна } \\
\text { для дитини; а через те будь-яке } \\
\text { втручання дорослого в гру позбавляє } \\
\text { іï дійсної, формуючої сили. Дитина не } \\
\text { тільки готується жити - вона вже живе. } \\
\text { Гра є вільною діяльністю дитини; у ній } \\
\text { формуються всі сторони людської душі } \\
\text { - розум, серце, воля }\end{array}$ \\
\hline $\begin{array}{l}\text { Дитина поєднується зі своїми } \\
\text { товаришами по грі, а ці останні } \\
\text { - зі своїм учителем. Перша гра... } \\
\text { хороводний танок. Саме я вивів взаємне } \\
\text { відношення місця зіткнення в житті } \\
\text { хороводу й центрального його пункту }\end{array}$ & $\begin{array}{l}\text { Під час колективних ігор виникають } \\
\text { перші асоціації з громадськими } \\
\text { відносинами; дитині, яка звикла } \\
\text { командувати або підкорятися в } \\
\text { грі, нелегко відучитися від цього у } \\
\text { дійсності }\end{array}$ \\
\hline
\end{tabular}

4. Звернути увагу на народні ігри, розробити це багате джерело, організувати їx і створити 3 них прекрасний і могутній виховний засіб - завдання майбутньої педагогіки.

5. В іграх, придуманих Фребелем, багато штучного й недитячого. Пісеньки здебільшого нудні, неприродні, написані дуже поганими віршами, які, за словами швейцарського педагога Фреліха, можуть тільки псувати смак дитини, а головне, пройняті нестерпним для дітей дидактизмом. 
6. Проте ігри Фребеля, а ще більш придумані ним або зібрані дитячі заняття, мають багато переваг і в руках доброї наставниці дають чимало користі.

7. Звичайно, заняття та ігри Фребеля, полегшують виховательці працю, дають їй засоби, яких вона сама може не знайшла б так швидко.

8. Багато з його дитячих занять потрібно впровадити не тільки в дитячих притулках, але й у всіх малолітніх школах і в молодших класах навчальних закладів [8, с. 202-204].

Грунтовний аналіз наукового спадку Ф. Фребеля дозволив К. Ушинському сформулювати такі педагогічні висновки щодо гри:

- ігри передбачають майбутній характер і долю дитини; сама гра має великий вплив на розвиток дитячих здібностей і нахилів;

- вихователь має великий вплив на гру дитини (навчаючи ії грі, підбираючи товаришів, даючи ідею ігор, надаючи їй засобів для виконання дитячих фантазій, припиняючи гру, якщо вона шкідливо впливає на дитину);

- дитячі ігри мають свої національності, свою багатовікову історію;

- це могутній виховний засіб, який виробило саме людство і в якому через це виявилась непідробною істинна потреба людської природи;

- велику послугу справі виховання зробив би той педагог, який вивчив докладно якнайбільшу кількість дитячих ігор і, випробувавши їх на практиці 3 дітьми, проаналізував їх психічний вплив на дитячі характери;

- діти безперестанно творять нові ігри, пристосовуючись до місцевості, речей, обставин, дня;

- у певній грі дитина зазнає труднощів і страждань у зв'язку з тією душевною діяльністю, яку дає гра (що в дорослому житті забезпечуватиме іiі життєве щастя) [10, с. 332].

Ми приєднуємося до думки К. Ушинського: «Ми надаємо такого великого значення дитячим іграм, що коли б влаштовували вчительську семінарію, чоловічу чи жіночу, то зробили б теоретичне й практичне вивчення дитячих ігор одним із головних предметів» [10, с. 333].

\section{4. Реалізація ідей Ф. Фребеля та К. Ушинського у професійно-педагогічній підготовці}

Розглядаючи педагогіку Ф.Фребеля як засіб фізичного прогресу дитини та індивідуального розвитку особистості, ми запропонували студентам опанувати методику дидактично-словесних ігор і застосо- 
вувати здобуті компетентності у процесі проведення уроку фізичної культури з молодшими школярами. Нами розроблені словесн ігри 3 використанням дарів Ф. Фребеля, які побудовані за принципом інтеграції навчальних дисциплін. Наприклад, моделююча гра «Покрокові дії при організації словесних ігор з першим дарунком Ф. Фребеля» об'єднувала такі освітні галузі знань як «мовно-літературна та іншомовна», «соціальна і здоров'язбережна», «мистецька», «технологічна та інформаційна».

План практичного заняття висвітлював такі запитання:

1. Принцип природовідповідності у педагогіці Ф. Фребеля (Фребелівська трактовка) [12, с. 46].

2. Дидактичний матеріал для навчання дітей, запропонований Ф. Фребелем (огляд першого дарунка).

3. Визначення поняття «Дарунки для дитячих ігор Ф. Фребеля». Які предмети входять до їх складу? Які рухливі ігри можна 3 ними проводити?

4. Діагностичний інструментарій для вивчення змістових конфігурацій готовності майбутніх учителів фізичної культури до роботи 3 «дарунками» Ф.Фребеля у подальшій професійній діяльності.

5. Принципи складання авторських словесних рухливих ігор і презентаційний супровід до них.

У процесі проведення практичного заняття на тему: «Покрокові дії при організації словесних ігор з першим дарунком Ф. Фребеля у колі» використовували розвивальний потенціал технологій ігрового моделювання за додержанням низки вимог:

- постановка навчальних цілей гри з використанням конкретного «Дарунку» - це іграшки, предмети у формі м'яча, кулі, куба, циліндра, маленьких кубиків, які можна ефективно використовувати у фізичному вихованні; формулювання дидактичної мети; аргументація значення гри; визначення інтенсивності;

- визначення кількісті учасників гри;

- дидактичний інструментарій;

- покрокове пояснення правил гри;

- організація самостійної роботи всіх учасників гри, результати якої підкріплювалась презентаціями в хмарному онлайн сервісі Prezi;

- оцінка самостійної роботи студентів і підведення підсумків. 
Одним із методів роботи, що дозволяв повно і раціонально використати перевагу і розвивальний потенціал ігрових технологій Ф. Фребеля у процесі підготовки майбутніх учителів фізичної культури, став метод ігрового проектування. Наведемо приклад ігор в колі з використанням першого дарунку.

1. Назва гри: «Швидко передай м’яч» (інтеграція 3 англійською мовою, математикою).

2. Визначення дидактичної мети: у роботі з дошкільниками вчать використовувати м'яч у грі як предмет-замінник, для ознайомлення 3 кольорами, навчання дітей орієнтації у просторі. У роботі з молодшими школярами м'яч слугує засобом ознайомлення з геометричними поняттями - формою (кругла), лінією (крива). У процесі фізичного виховання він розвиває фізичні якості, формує координаційні здібності дитини та вчить його діяти у команді вже з малку.

3. Аргументація значення гри: зміст гри містить у собі різноманітні види кроків, ходьби, бігу по колу, або на місці, підскоки і перебудовування з кола в лінії. Основні завдання для вчителя: навчити дітей зберігати заданий інтервал;максимально активізувати увагу при зміні команд (робота з кульками різного кольору);синхронність (виконання рухів під музику), одночасність зміни вправ (після нового пояснення гри у віршованій формі), розвиток швидкості, спостережливості, пом'яті, уважності, логіки та вивчення кольорів;

4. Визначення інтенсивності гри: середня.

5. Визначення кількості учасників: 10-12 дітей старшого дошкільного або молодшого шкільного віку.

6. Дидактичний інструментарій: 6 кольорових м'ячів, обмотаних шерстю, пофарбованих в кольори веселки (червоний, жовтий, блакитний, помаранчевий, зелений і фіолетовий) (перший дарунок Ф. Фребеля).

7. Пояснення змісту та правил гри «покроково» українською та англійською мовами:

Крок 1. На певній відстані стоїть порожній кошик. Діти (студенти у ролі дітей) утворюють коло сидячи на килимі, у центрі якого лежать кольорі кульки. Вчитель фізкультури (студент) просить їх зберігати тишу і лише тоді пояснює правила гри у віршованій формі пошепки (рис. 1, рис. 2).

Крок 2. Вчитель пропонує дитині (наприклад, студентці Наталці) обрати кульку (червону). 
6 маленьких кульок у будинку сплять.

Люлі, люлі, люлечки,

Хочуть спати кулечки.

Розкривають ротики,

Позіха мов котики.

Треба бути всім як миика

Не збудить нікого нишком.

Тут встає червона/жовта/ зелена кулька

Хоче в гру вона пограти.

Сплюх-дідусь приніс корзину 1-2-3- івсе можливо Схема 2-

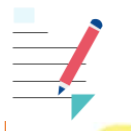
краЇнська версія

\section{Рис. 1. Вибір кульки для проведення словесної гри}

Крок 3. Вчитель промовляє наступні правила гри у віршованій формі:

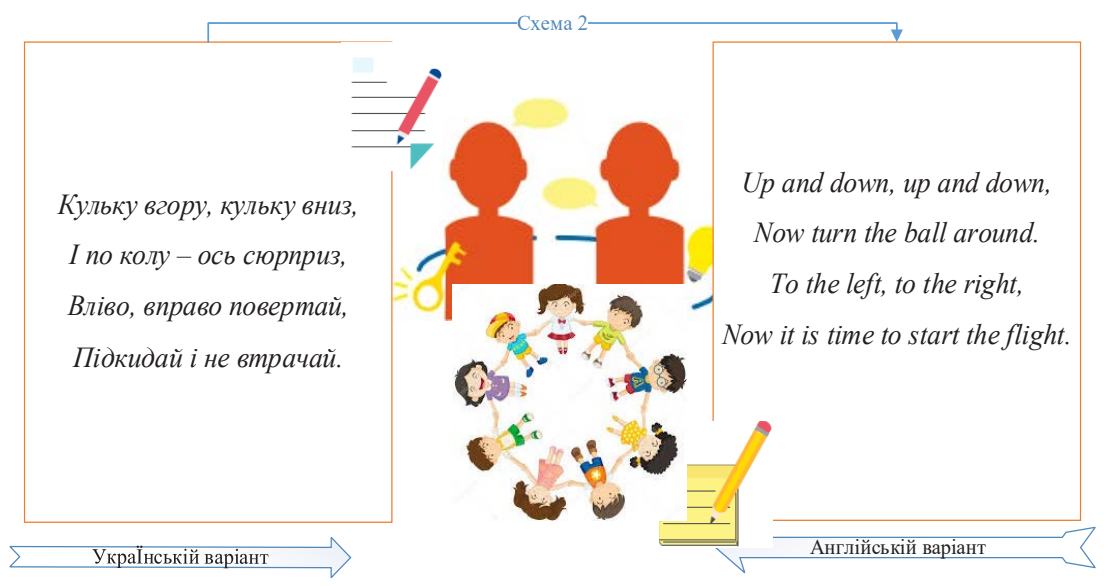

Рис. 2. Ознайомлення дітей із правилами гри 
Крок 4. Наталка виконує рухи 3 кулькою за вчителем під музичний супровід (діти повторюють рухи, але без предметів, застосовується метод «дзеркало») і передає червону кульку по колу доти вона не повертається до неї знов. Наталка встає зі свого місця і кладе червону кульку в корзину.

Крок 5. Гра починається знов з іншою кольоровою кулькою.

Етапами роботи над аналізом авторських ігор в аудиторії є: підбиття підсумків гри - оцінювання методичної і практичної вартості ігрових проектів; визначення їхньої ефективності та конкурентоспроможності у межах групи; логікою побудови гри; естетичним оформленням проекту (представлення мультимедійних проектів-презентацій, виконаних у програмі Prezi; представлення рішень кожної малої групи; загальна дискусія та питання; аналіз викладачем результатів діяльності через усну рефлексійну анкету:

1. Які нові знання, уміння, компетенції Ви отримали, поглибили, удосконалили?

3. У якій сфері професійно-педагогічної діяльності Ви зможете їх використовувати?

4. Які труднощі у Вас виникали при опрацюванні матеріалів теми та виконання самостійної роботи?

5. Чи знайшли Ви у представлених матеріалах ідею для впровадження STEM-освіти?

Після кожної презентації словесних ігор студентам було запропоновано оцінити за п'ятибальною школою, який з презентованих спікерами проектів не відповідає вимогам інтегрованого STEM-проекту 3 використанням дарунків Ф. Фребеля за табл. 3.

Фінальна стадія дуальних семінарських занять передбачала проведення невеликого загального анкетування. Студентам пропонували позначити одне твердження, яке найбільш точно передавало їх ставлення до STEM-освіти й ідей фізичного виховання у педагогічній спадщині Ф. Фребеля, зокрема:

1. Я позитивно сприймаю інновації щодо запровадження STEAMосвіти у фізичному вихованні з використанням дарунків Ф. Фребеля.

2. Я обережно ставлюся до реформ та інновацій у фізичному вихованні, зокрема до фребельпедагогіки.

3. Я негативно ставлюся до запровадження STEAM-освіти, фребельпедагогіки, оскільки це пов'язано з додатковим навантаженням і розробкою дидактичного інструментарію. 
Шкала оцінювання презентації словесних ігор

\begin{tabular}{|l|l|l|l|l|l|}
\hline \multicolumn{1}{|c|}{ Назва гри (бали) } & $\mathbf{1}$ & $\mathbf{2}$ & $\mathbf{3}$ & $\mathbf{4}$ & $\mathbf{5}$ \\
\hline $\begin{array}{l}\text { «Кульку передай та ім'я називай» } \\
\text { https://prezi.com/view/K6hRilqbkURQuxBunGPy/ }\end{array}$ & & & & + & \\
\hline $\begin{array}{l}\text { «Колискова для кульки» } \\
\text { https:/prezi.com/view/AsBO9xzH8vsQCaTWGySA/ }\end{array}$ & & & & + & \\
\hline $\begin{array}{l}\text { «Кольоровi рибки» } \\
\text { https://prezi.com/view/p1t3FmOjN5nUiFYhnNdR }\end{array}$ & & & + & & \\
\hline $\begin{array}{l}\text { «Футбол» } \\
\text { https://prezi.com/view/svFYMj49Y59pIkdn8UL0 }\end{array}$ & & & & & + \\
\hline $\begin{array}{l}\text { «3pyш з місця сніжку» } \\
\text { https://prezi.com/view/CxuIHHaDdfKYRWcFeASD }\end{array}$ & & & & + & \\
\hline
\end{tabular}

4. Не можу визначитися.

5. Свій варіант відповіді.

Сьогодні доцільним є раціональне використання правил «здорової» педагогіки та психології К. Ушинського у вихованні в школярів волі, звичок, уваги, розвитку їх фізичних і духовних сил, зміцнення та збереження здоров'я. Науковець називає ефективні форми влади душі над тілом - утримування від крику, ходьба, гімнастика (природна й навчальна), танці, співи. До найкращих засобів підтримання нормального стану організму належать фізичні вправи, гімнастика, здоровий сон та їжа, прогулянки на свіжому повітрі, холодні купання. Саме ці засоби «спартанського виховання» зміцнюють волю дитини і дають їй «владу над нервами».

В умовах побудови нової парадигми фізичного виховання дітей i молоді в Україні слушною є думка педагога про те, що «сидяче життя при 20-градусному теплі в кімнатах без будь-яких гімнастичних вправ, без прогулянок, без верхової їзди, без технічної роботи тощо, все за книгою та за книгою, то за уроком, то за романом»,- ось типове явище у вихованні дітей [10, с. 249].

Цінними $є$ рекомендації К. Ушинського щодо шляхів формування уваги й уважності, запобігання неуважності:

- засоби, що безпосередньо стимулюють увагу учня, дуже різноманітні; один із найкращих засобів - часте звертання до них; для постійно підтримки уваги корисно змушувати маленьких учнів робити 
по кілька дій за загальною командою (встати, сісти, розгорнути книги, згорнути тощо).

- загальна неуважність класу, сонливий його стан, загальне зниження рівня психофізичного життя, стан, що передує засинанню пояснюються фізичними і моральними причинами;

- фізичні причини неуважності: занадто тепло в кімнаті; замало кисню в повітрі, що часто буває в тісних і рідко провітрюваних клаcax; нерухомість тіла, переповнення шлунків, велика втома загалом [10, c. 262-263];

- ніщо так не схиляє дітей до сонливості та лінощів, як погане, важке повітря і задуха в класі; у кімнаті, де холод постійно нагадує про себе, також важко вчитися;

- додержання потрібної температури так само важливе для дітей, як для квітів, щоб підтримувати їх у бадьорому, збудженому стані, не кажучи вже про вплив цієї обставини на здоров'я [11, с. 156].

- моральні причини неуважності: монотонність та одноманітність звуків викладання; рутинність наставника, втома від одних і тих же занять тощо; щоб не дати дрімати класові, вчитель сам не повинен дрімати;

- увага самого наставника до своєї справи - це головний радикальний засіб проти загальної сонливості класу; але є ще паліативні заходи, до яких звичайно вдаються, а саме: класні співи; пісня, проспівана серед уроку, оживляє клас, будить його енергію; тілесний рух, невелика класна гімнастика, особливо для малих дітей тощо.

- струс уваги - захід, який не дає заснути людині, як струс рукою;

- заохочувальні засоби - нагороди за уважність і стягнення за неуважність, теж допускаються. Але треба, щоб ці засоби не були надто сильними, бо це тільки зіпсує справу.

- учитель не повинен забувати, що крик, лайка, погрози, надмірні похвали, насмішки й т. п. відвертають увагу замість того, щоб зосереджувати іiі, і за будь-яких умов погано впливають на моральність [10, с. 263-264].

\section{5. Висновки}

3 огляду на проведене дослідження, висновуємо:

1. Вивчення теорії дитячої гри в педагогічній концепції Ф. Фребеля показало, що вона грунтується на принципах дитино центризму, твор- 
чості, самодіяльності, саморозвитку дитини, забави, конструктивної діяльності через вираження дитячих почуттів, думок, жестів, пісень, оповідань. Вчений всебічно обгрунтував розвивальний, виховний та освітній потенціал дитячої гри та розробив їх цілісну дидактичну систему, що має пріоритетне та самостійне місце в системі дошкільного виховання.

2. К. Ушинський ігрову діяльність дітей як предмет спеціального педагогічного дослідження розгортає у працях «Людина як предмет виховання. Спроба педагогічної антропології» та «Звіт відрядженого за кордон», де визначає важливе значення гри у фізичному та психічному розвитку особистості, полемізує та критично оцінює «дитячі дарунки» Ф. Фребеля. Теоретичне та практичне вивчення дитячих ігор в сучасних умовах є важливою професійною компетентністю майбутніх учителів фізичної культури, методичні положення про їх доцільність обгрунтовував К. Ушинський.

3. Проведений історико-педагогічний аналіз праць Ф. Фребеля та К. Ушинського засвідчує важливі наукові здобутки педагогів у галузі теорії дитячої гри. Зазначимо, що К. Ушинському у шкільній практиці (під час перебування за кордоном у Німеччині, Швейцарії) доводилося спостерігати застосування ідей Ф. Фребеля у роботі дитячих садків Європи. Заслугою німецького педагога $є$ те, що він створив теорію і методику пізнання довкілля з «Дарами» в ігровій діяльності, яка грунтується на засадах поєднання сенсорної діяльності і розвитку мовлення дітей. Проте Ф. Фребель дещо перевантажував ігри та заняття складними філософськими поняттями. Ці та інші слабкі сторони методики роботи з дітьми дошкільного віку критикували педагоги К. Ушинський, Л. Толстой, С. Русова, Н. Лубенець.

4. Окреслено шляхи творчого використання ідей Ф. Фребеля у формуванні професійної мобільності майбутнього вчителя фізичної культури у процесі практичної підготовки до ігрової діяльності молодших школярів. Основними результатами застосування педагогіки Ф. Фребеля є розвиток і формування: навичок спільної діяльності, співпраці; почуття колективної відповідальності; аналітичного, прогностичного, дослідницького і творчого потенціалу; презентаційних умінь і навичок, комунікативної й інтерактивної компетентності студентів; практичних професійних навичок щодо застосування методики Ф. Фребеля у подальший професійній діяльності. 
Фребелівський дидактичний матеріал був спрямований на оволодіння студентами методикою розвиту фізичних здібностей дітей, їх здатності до конструктивної діяльності, логічного мислення, що набуває сьогодні особливої значущості не тільки у фізичному вихованні, але і у професійному спорті. Педагогіка Фребеля покликана виховувати у майбутнього вчителя не тільки фізичну культуру, але й «культуру» в широкому розумінні цього слова, формує його професійно-мобільні компетентності комбінаторного типу.

5. Визначено положення «здорової педагогіки» К. Ушинського, які оптимізують професійну підготовку мобільно спрямованого майбутнього вчителя фізичної культури в умовах нової української школи. Необхідними педагогічними умовами реалізації головних завдань фізичного виховання в науковому спадку К. Ушинського є дотримання принципів гуманізму, народності, природовідповідності, раціонального використання ефективних шляхів, засобів та форм зміцнення та збереження психічного та фізичного здоров'я школярів на вимогах сформованості високоморальних та професійних якостей особистості педагога. Перспективу подальших наукових розвідок із означеної проблеми вбачаємо у доцільності вивчення та використання ідей ігрової діяльності дітей в педагогічній спадщині Я. Коменського з метою формування професійно-мобільних компетенцій педагога нової української школи.

\section{Список літератури:}

1. Кравець В.П. Педагогічне вчення Фребеля. Історія класичної зарубіжної педагогіки та шкільництва. Тернопіль, 1996. С. 371-378.

2. Лесгафт П. Руководство к физическому образованию детей дошкольного возраста. Москва : Тип. Т-ва художественной печати, 1901. Ч. 2. 407 с.

3. Лубенець Н.Д. Фребель і Монтессорі. Хрестоматія з історії дошкільної педагогіки : навч. посіб. / за заг. ред. З.Н. Борисової. Київ : Вища школа, 2004. C. 283-290.

4. Монтессорі М. Метод наукової педагогіки, застосований до дитячого виховання в «Будинках дитини». Хрестоматія з історіїдошкільної педагогіки : навч. посіб. / за заг. ред. З.Н. Борисової. Київ : Вища школа, 2004. С. 104-120.

5. Про освіту. Закон України (Відомості Верховної Ради (ВВР), 2017, № 38-39, ст. 380). URL: https://zakon.rada.gov.ua/laws/show/2145-19\#Техt (дата звернення: 16.10.2020).

6. Русова С. Вибрані педагогічні твори. Київ : Освіта, 1996. 304 с.

7. Сбруєва А.А. Порівняльна педагогіка : навч. посіб. 2-ге вид., стер. Суми : Університетська книга, 2004. 320 с. 
8. Ушинський К.Д. Звіт про відрядження за кордон. Твори. В 6 т. Т. 2. Київ : Рад. шк., 1954. С. 174-260.

9. Ушинський К.Д. Людина як предмет виховання (Спроба педагогічної антропології). Твори. В 6 т. Т. 4. Київ : Рад. шк., 1952. С. 21-454.

10. Ушинський К.Д. Стислий підручник педагогіки. Твори. В 6 т. Т. 6. Київ : Рад. шк., 1955. С. 237-402.

11. Ушинський К.Д. Твори. В 6-ти т. Т. 1. Педагогічні статті / відп. за укр. вид. Г.С. Костюк, С.Х. Чавдаров. Київ : Рад. шк., 1954. 449 с.

12. Фребель Ф. Воспитание человека. История дошкольной и зарубежной педагогики. Москва : Просвещение, 1974. С. 46.

13. Фребель Ф. Дитячий садок. Хрестоматія з історії дошкільної педагогіки : навч. посіб. / за заг. ред. 3.Н. Борисової. Київ : Вища шк., 2004. С. 67-103.

14. Korczak J. Jak kochac dziecko. Dziecko w rodzinie. Warszawa-Krakow: Wydawnictwo J. Mortkowicza. TowarzystwoWydawnicze w Warszawie, 1929. 168 s.

\section{References:}

1. Kravets, V.P. (1996). Pedahohichne vchennia Frebelia [Pedagogical doctrine of Froebel]. Istoriia klasychnoi zarubizhnoi pedahohiky ta shkilnytstva-History of classical foreign pedagogy and schooling. (in Ukrainian)

2. Lesgaft, P. (1901). Rukovodstvo k fizicheskomu obrazovaniyu detey doshkolnogo vozrasta [Guide for physical education of children of preschool age]. Moskva: Tip. T-va hudozhestvennoy pechati. (in Russian)

3. Lubenets, N.D. (2004). Froebel i Montessori [Froebel i Montessori]. Z.N. Borysova (Eds.). Khrestomatiia z istorii doshkilnoi pedahohiky - Anthology of the history of preschool pedagogy: textbook. Kyiv: Vyshcha shkola. (in Ukrainian)

4. Montessori, M. (2004). Metod naukovoi pedahohiky, zastosovanyi do dytiachoho vykhovannia v «Budynkakh dytyny» [The method of scientific pedagogy applied to children's education in "Children's Homes"]. Z.N. Borysova (Eds.). Khrestomatiia z istorii doshkilnoi pedahohiky - A reader on the history of preschool pedagogy: textbook. Kyiv: Vyshcha shkola. (in Ukrainian)

5. Zakon Ukrainy «Pro osvitu» [The Law of Ukraine "About education"]. (n.d.). zakon.rada.gov.ua. Retrieved from: https://zakon.rada.gov.ua/laws/show/ 2145-19\#Text (in Ukrainian)

6. Rusova, S. (1996). Vybrani pedahohichni tvory [Selected pedagogical works]. Kyiv: Osvita. (in Ukrainian)

7. Sbruieva, A.A. (2004). Porivnialna pedahohika [Comparative pedagogy] (2-nd ed.). Sumy: Universytetska knyha. (in Ukrainian)

8. Ushynskyi, K.D. (1954). Zvit pro vidriadzhennia za kordon [Report on a business trip abroad]. Tvory - Compozitions, vol. 2, pp. 174-260. Kyiv: Rad. shk. (in Ukrainian)

9. Ushynskyi, K.D. (1952). Liudyna yak predmet vykhovannia (Sproba pedahohichnoi antropolohii) [Man as a subject of education (An attempt of pedagogical anthropology)]. Tvory - Compozitions, vol. 4, pp. 21-454. Kyiv: Rad. shk. (in Ukrainian) 
10.Ushynskyi, K.D. (1955). Styslyi pidruchnyk pedahohiky [Brief textbook of pedagogy]. Tvory - Compozitions, vol. 6, pp. 237-402. Kyiv: Rad. shk. (in Ukrainian)

11. Ushynskyi, K.D. (1954). Tvory [Compozitions]. H.S. Kostiuk, S.Kh. Chavdarov (Eds.), Pedahohichni statti - Pedagogical articles, vol. 1-6. Kyiv: Rad. shk. (in Ukrainian)

12. Froebel, F. (1974). Vospitanie cheloveka [Education of the person]. Istoriya doshkolnoy i zarubezhnoy pedagogiki - History of preschool and foreign pedagogy. Moskva: Prosveshchenye. (in Russian)

13.Froebel, F. (2004). Dytiachyi sadok [Kindergarten]. Z.N. Borysova (Eds.). Khrestomatiia $z$ istorii doshkilnoi pedahohiky - A reader on the history of preschool pedagogy: textbook. Kyiv: Vyshcha shkola. (in Ukrainian)

14. Korczak, J. (1929). Jak kochac dziecko. Dziecko w rodzinie [How to love a child. A child in the family]. Warszawa-Krakow: Wydawnictwo J. Mortkowicza. Towarzystwo Wydawnicze w Warszawie. 